Indian J Anim Health (2021), 60(1) : 01-09

DOI:10.36062/ijah.60.1.2021.01-09

\title{
Biotechnological potential of stem cells in food-producing animals: A review
}

\author{
N. Shah ${ }^{1 *}$, M. Sethi ${ }^{1}$, D. K.Yadav ${ }^{1}$, P. Kumar ${ }^{1}$, A. Soe ${ }^{1}$, S. Nath ${ }^{2}$, \\ M. Bhakat ${ }^{3}$ and T. K. Mohanty ${ }^{4}$
}

${ }^{1}$ Department of Animal Reproduction, Gynaecology and Obstetrics, ICAR-National Dairy Research Institute, Karnal-132 001, Haryana, India; ${ }^{2}$ Artificial Breeding Research Centre, ICAR-National Dairy Research Institute, Karnal-132 001, Haryana, India; ${ }^{3}$ Division of Livestock Production Management, Artificial Breeding Research Centre, ICAR-National Dairy Research Institute, Karnal-132 001, Haryana, India; ${ }^{4}$ Department of Animal Reproduction, Gynaecology and Obstetrics, Artificial Breeding Research Centre, ICAR-National Dairy Research Institute, Karnal-132 001, Haryana, India

\begin{abstract}
Animal biotechnology related to production has contributed to many improvements in agriculturally important traits in livestock. Although, artificial insemination was the first assisted reproductive technology used to enhance farm animal reproduction and propagate superior genetics, reproductive cloning and the development of transgenic animals are the most current of these new technologies. Reproductive biotechnology can be used to propagate superior genetics in considerably less time than traditional breeding methods. Genetic manipulation based on the selection of phenotypic traits has been long practiced in animal agriculture. Artificial insemination, embryo transfer and in vitro fertilization have added significant improvement in livestock development. Cloning shortens the generation period without altering the genetic composition, thereby helps to provide superior livestock that can replace low-productive animals. Cloning can be done by using stem cell, usages of stem cells in reproductive cloning serves to be useful biotechnology to create a transgenic animal.
\end{abstract}

Key words: Cloning, Livestock, Stem cell, Transgenic animal

\section{Introduction}

' Stem cells are unspecialized or undifferentiated cells that can transform into any cell type i.e. specialized or differentiated cells. Stem cells can be isolated from an embryo, fetus, or adult tissue or a cell that can reproduce themselves for a longer period of time under certain conditions (Table 1) (Zakrzewski et al., 2019). They are categorized as totipotent, pluripotent, or multipotent cells depending on their stage of development and differentiation (Table 2) (Weissman and Wagers, 2004). This review will target the applications of stem cells to increase the productive trait of livestock.

Table 1. Types of stem cells (Based on sources)

\begin{tabular}{ll}
\hline \multicolumn{1}{c}{ Origin } & \multicolumn{1}{c}{ Stem cell type } \\
\hline Blastocyst (ICM) & Embryonic stem cell (ESC) \\
\hline $\begin{array}{l}\text { The gonadal ridge of a fetus (e.g. Primordial germ cells) } \\
\text { from 5-10 weeks of fetus }\end{array}$ & Embryonic germ (EG) cells \\
\hline $\begin{array}{l}\text { Embryonal carcinoma (e.g. PGC), the component of } \\
\text { testicular tumors of adult }\end{array}$ & Embryonic carcinoma (EC) cells \\
\hline Umbilical cord & Umbilical cord stem cells \\
\hline Placenta of newborn & Placental stem cells \\
\hline Amniotic fluid & Amniotic fluid stem cells \\
\hline $\begin{array}{l}\text { Adult tissues: e.g. liver, brain, skin, cornea, retina, } \\
\text { skeletalmuscle, dental pulp, pancreas, endothelial } \\
\text { progenitors (EPCs), etc. }\end{array}$ & Adult stem cells \\
\hline
\end{tabular}

*Corresponding author 
Table 2.Types of stem cell (Based on potency)

\begin{tabular}{lll}
\hline Type & \multicolumn{1}{c}{ Description } & \multicolumn{1}{c}{ Example } \\
\hline Totipotent & Each cell can develop into a new individual & Cells from early embryo (1-3 days) \\
\hline Pluripotent & Cells that can give rise to all adult cell types & Some cells of a blastocyst (5-9 days) \\
\hline Multipotent & Differentiated cells \& cells of other tissue & Adult stem cells \\
\hline Unipotent & Cells from only one cell type & $\begin{array}{l}\text { Spermatogonial stem cells } \\
\text { (sperm)/oocyte }\end{array}$ \\
\hline
\end{tabular}

\section{Application of stem cells}

The effective use of stem cells in livestock production has shown to be a valuable technique (Table 3). Stem cells have applications in a various field such as-

Use of stem cell in human: ESC can be used for cardiac repair (heart disease), neurological disorders, diabetes, spinal cord injury, Parkinson's and genetic diseases (Hassan et al., 2009).

Therapeutic use of animal ES cells: Domestic animals are immunologically and physiologically more similar to humans than rodent models, and domestic animals may be used as a model for studying human pathology (Vandamme et al., 2014). Animal ES cells can be used as a model for human research (Blastocyst complementation) (Crane et al., 2019)

Table 3. Biotechnological potential of stem cells in food-producing animals

\begin{tabular}{|c|c|c|}
\hline Species & Potential application & Reference \\
\hline Cattle/Buffalo & $\begin{array}{l}\text { Enhancing milk and meat production, } \\
\text { enhancing biopharming through transgenic } \\
\text { milch animals; reduction in emissions of } \\
\text { greenhouse gases; production of meat in vitro }\end{array}$ & $\begin{array}{l}\text { Singh et al., 2009; } \\
\text { Niemann et al., 2011; } \\
\text { Singh et al., } 2011\end{array}$ \\
\hline Pig & $\begin{array}{l}\text { Developing cells, tissues and organs for xeno- } \\
\text { transplantation, enhancing biopharming } \\
\text { through transgenic animals, production of } \\
\text { pork in vitro }\end{array}$ & Niemann et al., 2011 \\
\hline Goat and Sheep & $\begin{array}{l}\text { Enhancing biopharming through transgenic } \\
\text { animals, in vitro mutton/chevon production } \\
\text { and conservation of genetic diversity through } \\
\text { repopulation of endangered species }\end{array}$ & $\begin{array}{l}\text { Mauro et al., 2010; } \\
\text { Azari et al., } 2011\end{array}$ \\
\hline Poultry & $\begin{array}{l}\text { Transgenic chicken with higher growth rate, } \\
\text { increase in dark and white muscle, producing } \\
\text { low cholesterol egg }\end{array}$ & $\begin{array}{l}\text { Mozdziak et al., 2003; } \\
\text { Ricks } \text { et al., 2003; } \\
\text { Li et al., } 2008\end{array}$ \\
\hline
\end{tabular}

Use of stem cell in livestock: ESC can be used to improve the efficiency of the somatic cell nuclear transfer (SCNT)/cloning technique, production of transgenic and chimeric animals, gene targeting and genome editing, production of germ cells to treat infertility, screening of drug and chemicals, as well as for the studies on early embryonic development, DNA methylation/genomic imprinting (Vijayalakshmy et al., 2018).

Application of stem cells in food-producing animals:

$\checkmark$ Transgenic animals: Embryonic stem cellmediated gene transfer

$\checkmark$ Gene targeting (Myostatin)

$\checkmark$ Cloning

$\checkmark \quad$ In vitro meat production/cultured meat production (Yadav et al., 2012) 


\section{Role of stem cells in food producing animal}

\section{Transgenic animals}

In the 1980s, several transgenic animals were reported to have been created. Several approaches are used to produce transgenic animals.The micro-injection approach is widely utilized, although it has some disadvantages, including low efficiency and variable expression patterns. So, various alternative techniques such as sperm-mediated DNA transfer (Chang et al., 2002), intracytoplasmic injection (Umeyama et al., 2012), nuclear transfer (Carvalho et al., 2019) technologies, injection or infection of oocytes and/or embryos by different types of viral vectors (Clark and Whitelaw, 2003) and ribonucleic acid (RNA) interference technology (Xu et al., 2019) have been developed.

Transgenic animals are organisms that have had incorporated cloned DNA sequences (transgenes) that have been transferred using genetic engineering techniques (including gene transfer and gene substitution). Several types of transgenic animals like transgenic cow, bull, sheep, pig, etc. were produced for the better and good quality breed with increased milk yield and meat production. Genetically modified animals are proving ever more vital in the development of new treatments and cures for many serious diseases (Feng et al., 2020).

Advantages of transgenic animals for enhancing animal productivity:

$\checkmark$ Increase the growth performance

$\checkmark$ Improve the feed conversion efficiency

$\checkmark$ Increase the muscle mass and mutton production

$\checkmark$ Improve the nutritional quality of milk

$\checkmark$ Improve the wool quality (fineness, luster)
Methods for producing transgenic animals: The introduction of a foreign gene or genes into an animal is the primary principle in the development of transgenic animals. Transmission of the foreign genes through germlines must be there to ensure that every cell of the animal contains the same modified genetic material.

Embryonic stem cell-mediated gene transfer: In 1981, the term embryonic stem cells (ES cells) were used to denote a cell line isolated directly from mouse embryos while the term embryonal carcinoma cells (EC) were derived from teratocarcinoma. ES cells are harvested from the inner cell mass (ICM) of mouse blastocysts. They can be grown in culture and retain their full potential to produce all the cells of the mature animal, including its gamete (Zhang et al., 2020).

Gene targeting based transgenesis: Gene targeting is a technology that specifically modifies a particular gene in the chromosome through homologous recombination and integrates extrinsic genes into the specific target site. Gene targeting technology overcomes random integration events and is therefore ideal for the modification and reconstruction of biological genetic materials (Miao, 2013).

Embryonic stem cell gene targeting: ESC gene targeting takes advantage of embryonic stem cells' totipotency to insert modified extrinsic genes into ESCs that can then be inserted into animal blastula/blastocysts. The ESCs will participate in the formation of host embryos, construct chimera until species chimerism, and transmit the extrinsic gene to the next generation and produce transgenic animals (Suchy and Nakauchi, 2017).
Benefits an animal that requires few feed supplements as well as medical treatments.

2. A desired characteristic of offspring could be established in one generation.

3. The characteristic required can be chosen with greater specificity and accuracy.
1. Insertion of a foreign gene may upset the expression of the genome.

2. Normal reproduction may result in a transgene being released to the wild population. 
ESC gene targeting technology was used to build a mouse model with a hypoxanthineguanine phosphoribosyltransferase (HPRT) knockout. Through gene targeting, current techniques can not only knock out specific genes but also transfer extrinsic genes into the animal genome to obtain gene knock-in animals. Targeted disruption of the myostatin (mstn) gene in yellow catfish was performed using engineered zinc-finger nucleases (ZFNs), and six mstn ${ }^{\text {nju6/+ }}$ and $14 \mathrm{mstn}^{\text {nju } 7 /+}$ offspring were obtained. p53 (also known as Tp53) gene knockout rats were generated by homologous recombination in embryonic stem (ES) cells. The entire process requires $\sim 1$ year of completion, from the derivation of ES cells to the generation of knockout rats (Hall et al., 2009).

ES cells provide a system for studying the whole cellular population. By the utilization of ES cells as a carrier and the modification of ES cells in vitro, all issues including the numbers, the loci, and the expression extent of integrated genes, the stability of inserted genes, and the screening of genes can be finished on a cellular level. Currently, homologous recombination in ES cells becomes one common technique to modify any gene site in the mouse chromosome and is applied to study gene function and disease models. However, ES cells from domestic animals have not been obtained for gene targeting so far, which thereby limits the application of gene targeting for production such as mammary gland bioreactor (Monzani et al., 2016).

\section{Transgenic Cattle:}

$\checkmark$ The transgenic cow produces lactoferrin and interferons (Li et al., 2014).

$\checkmark$ Myostatin gene is used for double muscling in cattle (Monin and Sante-Lhoutellier, 2014).

$\checkmark$ Transgenic cattle containing two extra copies of kappa casein increase the $13 \%$ more proteins (Laible et al., 2016).

$\checkmark$ Lactose-free milk (transgene lactase) has been produced (Shepelev et al., 2018). $\checkmark$ Resistance to bacterial infections/prion free cow has been produced (Richt et al., 2007) Transgenic Sheep:

$\checkmark$ Producing $\alpha$-antitrypsin in their milk (Viglio et al., 2020)

$\checkmark$ Myostatin gene used for double muscling (Miar et al., 2014)

\section{Transgenic Pig:}

$\checkmark$ Containing a human metallothionein promoter or porcine growth hormone gene construct referred to significant improvements in economic traits including growth rate, body fat/muscle ratio (Ju et al., 2015).

$\checkmark$ Containing spinach desaturase gene in their genome which produces a large amount of non-saturated fatty acids in its pork which when consumed by humans reduces the risk of stroke and coronary disease (Niemann, 2004).

Transgenic Goat: Tissue plasminogen activator, antithrombin III (He et al., 2018), spider silk (Decker, 2018), lysozyme (Yu et al., 2013), and lactoferrin (Zhang et al., 2015) has been produced in their milk.

Transgenic Fish: A superfish has been produced by inserting the growth hormone gene into eggs and enhanced the body weight more than 10-11 times faster than the normal fish (Kurdianto et al., 2016).

\section{Cloning}

Nuclear cloning is a process in which a diploid nucleus is injected into an enucleated egg and allows them to develop up to the blastocyst stage or full term. It is a technique to create genetically identical organisms (Rogers, 2016).

Types of cloning: a) Embryo cloning: to produce monozygotic twins or triplets from a fertilized embryo- single cell can develop an embryo, b) Reproductive cloning: to create clone animals, c) Therapeutic cloning: to produce stem cells for regenerative medicine. 
A clear advantage of cloning is to conserve breeds or species (particularly those are endangered), thereby maintaining or increasing genetic diversity in the population (Bazer et al., 2012). Cloning can also allow castrated male animals that possess good traits (e.g., high-quality meat, as well as unusually high rates of lean tissue growth and feed efficiency) to pass their genetic traits to offspring.

The United States Food and Drug Administration (FDA, 2018) published an article stating that "meat and milk from clones of cattle, pigs, goats, and the offspring of clones from any species traditionally consumed as food, are as safe to eat as food from conventionally bred animals".

ES cells have 10-20 folds higher efficiency as somatic cell nucleus donors in cloning than cumulus cells (Jaenisch et al., 2002). Genetic modification by homologous recombination is higher in ES cells than in somatic cells, hence there is higher efficiency of transgenic animal production by nuclear transfer (Burgio, 2018).

\section{In vitro meat production/ cultured meat production}

Meat produced from cell cultures is a prominent alternative for traditional meat derived from live animals (Slade, 2018). This approach gained increasing attention in public opinion, popular media, animal welfare organizations, the scientific community, and among investors (Stephens et al., 2018), particularly after the production of the first clean meat prototype (Post and van der Weele, 2014).

According to an FAO survey, livestock accounts for 14.5 percent of global greenhouse gas emissions, 30 percent of Earth's terrain, and $8 \%$ of global freshwater (Gerber et al., 2013). Traditional meat processing systems cannot be considered viable with global meat demand predicted to double by 2050 .

Food-borne illnesses such as swine and avian influenza are often caused by intensive factory farming and poor animal health conditions. They also contribute to the spreading of E.coli, salmonella, and campylobacter, which can be found in meat (Anomaly, 2015). Overuse of antibiotics induces the selection of antimicrobial-resistant (AMR) strains, a major human health concern (Tang et al., 2017). Ethical concerns regarding factory farms (Herzog, 2016) and the slaughter of animals are another drive behind clean meat research (Sharma et al., 2015).These issues could be avoided and food safety could be enhanced by processing meat in a sterile and controlled environment.

Methods of production of in vitro/cultured meat: For the realization of the concept, two major technologies have been created. The biotechnological approach, which broadly includes cell and tissue culture, is at the core of the scheme and based on their design, they are also popularly known in the jargon of biotechnology as 'Scaffold based' and 'Selforganizing techniques', respectively (Edelman et al., 2005).

1. Self-organizing technique: The first method involves using an explant from a donor animal's muscle, which is then multiplied in a nutrient medium. The origins of the term can be traced back to the early $21^{\text {st }}$ century when tissueengineering methods were used to grow meat (Benjaminson et al., 2002). They placed skeletal muscle explants from goldfish (Carassius auratus) in diverse culture media and observed a varied pattern of growth, concerning an increase in surface area over 7 days. The results based on the medium were as - fetal bovine serum: $13.8 \%$, fish meal extract: $7.1 \%$, shiitake extract: $4.8 \%$, maitake extract: $15.6 \%$. Explants were also put in a culture of dissociated Carassius skeletal muscle cells, which resulted in a 79 percent increase in the explant surface region.The self-organizing technique helps to create structured meat i.e. meat produced will have a well-defined 3-D structure, just as the natural conformation of meat. The same can be achieved using the principles of tissue engineering for de novo synthesis of muscle tissue (Edelman et al., 2005). 
2. Scaffold-based technique: The second method of culturing meat involves suitable stem cells which can be obtained from a variety of tissues. The scaffold-based technique involves proliferating embryonic myoblasts or adult skeletal muscle satellite cells, adding them to a scaffold or carrier, and then perfusing them with a culture medium in a bioreactor (Kosnik et al., 2003).The scaffold-based technique operates on the concept of appropriate muscle cells proliferating on a scaffold in the presence of a culture medium in a bioreactor. Myofibers are produced as a result of this culturing, which can then be harvested, processed, and consumed as meat or meat products (Bhat and Fayaz, 2011).

There are currently two elaborated propositions for using cell culture to create meat in the lab. One has been written by Vladimir Mironov for NASA (Wolfson, 2002), while the other by Willem van Eelen who holds a worldwide patent for a similar system (Van Eelen et al., 1999). Vladimir Mironov proposed that cells be grown on collagen spheres where they would attach and differentiate in a bioreactor. Willem van Eelen proposed using collagen meshwork instead of spheres and regularly refreshing the culture medium. Collagen may be replaced by other edible proteins or artificial substrates if the culture medium is percolated through the meshwork (Van Eelen et al., 1999). After harvesting, it can also use two-dimensional monolayers of muscle cells sandwiched together (Bhat and Fayaz, 2011). This method is expected to be suitable for the production of processed ground meat products, but not for the production of highly structured meats like steaks. To produce organized muscle tissue, a more refined approach such as Self Organising Technique is needed (Edelman et al., 2005). The meat is majorly composed of skeletal muscle which consists of several cell types. Proliferation, differentiation, and fusion of embryonic

\section{REFERENCES}

Anomaly J, 2015. What's wrong with factory farming? Public Health Ethics, 8(3): 246-54, doi: 10.1093/phe/phu001 myoblasts or satellite cells result in the development of skeletal muscle fibers (Langelaan et al., 2010). Several cell types have been proposed for the in vitro meat production system by several authors; these are Myosatellite cells, ESCs, and Adult stem cells. Satellite cells, also known as myoblasts, are responsible for muscle regeneration and can quickly differentiate into myofibrils. Stem cells, on the other hand, can differentiate into various cell types and are predominantly located in the early stages of organism growth (Williams, 2012).

\section{Conclusion}

Stem cells are a powerful tool for improving livestock performance and in vitro meat production in a controlled, animal-free environment. It will necessitate a change in optimization parameters, with a greater emphasis on low-cost, animal-free biomaterials, effective farm animal cell expansion, intramuscular fat tissue engineering, and analysis methods that emphasize nutritional value and organoleptic properties. The use of stem cell technology would assist in dealing with limited resource supply and a related rise in the demand for food production. Producers can elicit rapid genetic change to create the next generation of superior animals. Transgenic methodologies may also help both farmers and consumers by incorporating new genes into a population. Cloning and precise placement of genetic information will undoubtedly become the most useful approach to generat potential transgenic livestock because it is vastly more productive than other types of transgenesis. Cloned and transgenic livestock will continue to be developed, but consumer acceptance is needed to realize their full potential and effect on animal health and food security.

Conflict of interest: Authors have no conflict of interest in this study.

Azari O, Babaei H, Derakhshanfar A, NematollahiMahani SN, Poursahebi R et al., 2011. Effect of transplanted mesenchymal stem cells isolated 
from Wharton's jelly of caprine umbilical cord on cutaneous wound healing; histopathological evaluation. Vet Res Commun, 35(4): 211-222, doi: $10.1007 / \mathrm{s} 11259-011-9464-\mathrm{Z}$

Bazer FW, Kraemer DC and McHughen A, 2012. Welfare, health and Biological Efficiency through Genetics and Biotechnology. In: Pond WG, Bazer FW, Rollin BF, editors, Animal Welfare and Animal Agriculture: Husbandry, Stewardship and Sustainability in Animal Production. Boca raton: CRC Press, pp 275-290

Benjaminson MA, Gilchriest JA and Lorenz M, 2002. In vitro edible muscle protein production system (MPPS): stage 1, fish. Acta Astronaut, 51(12): 879889, doi: 10.1016/S0094-5765(02)00033-4

Bhat ZF and Fayaz H, 2011. Prospectus of cultured meat- advancing meat alternatives. J Food Sci Technol, 48: 125-140, doi: 10.1007/s13197010-0198-7

Burgio G, 2018. Redefining mouse transgenesis with CRISPR/Cas9 genome editing technology. Genome Biol, 19(1): 1-3, doi: 10.1186/s13059018-1409-1

Carvalho BP, Cunha AT, Silva BD, Sousa RV, Leme LO et al., 2019. Production of transgenic cattle by somatic cell nuclear transfer (SCNT) with the human granulocyte colony-stimulation factor (hG-CSF). J Anim Sci Technol, 61(2): 61-68, doi: $10.5187 /$ jast.2019.61.2.61

Chang K, Qian J, Jiang M, Liu YH, Wu MC et al., 2002. Effective generation of transgenic pigs and mice by linker-based sperm-mediated gene transfer. BMC Biotechnol, 2: Article no. 5, doi: 10.1186/1472-6750-2-5

Clark J and Whitelaw B, 2003. A future for transgenic livestock. Nat Rev Genet, 4(10): 825-833, doi: $10.1038 / \mathrm{nrg} 1183$

Crane AT, Aravalli RN, Asakura A, Grande AW, Krishna VD et al., 2019. Interspecies organogenesis for human transplantation. Cell Transplant, 28(9-10): 1091-1105, doi: 10.1177/096368971984 5351

Decker Jr RE, 2018. Production and Biocompatibility of Spider Silk Proteins in Goat Milk. All Graduate Theses and Dissertations, 7288, https:/ /digitalcommons.usu.edu/etd/7288

Edelman PD, McFarland DC, Mironov VA and Matheny JG, 2005. Commentary: In vitro cultured meat production. Tissue Eng, 11(5-6): 659-662, doi: 10.1089/ten.2005.11.659

Kurdianto, Alimuddin, Faridah N, Yoshizaki G, Nuryati S et al., 2016. Growth, survival, and body composition of transgenic common carp
Cyprinus carpio $3^{\text {rd }}$ generation expressing tilapia growth hormone cDNA. Hayati J Biosci, 23(3): 150-154, doi: 10.1016/ j.hjb.2016.12.002

Feng G, Jensen FE, Greely HT, Okano H, Treue S et al., 2020. Opportunities and limitations of genetically modified nonhuman primate models for neuroscience research. PNAS, 117(39): 24022-24031, doi: 10.1073/pnas.2006515117

Food and Drug Administration (FDA, United States), 2018. FDA approves its first human biogenic produced by GE animals. FDA Veterinarian News Letter, XXIII(VI)

Gerber PJ, Steinfeld H, Henderson B, Mottet A, Opio C et al., 2013.Tackling climate change through livestock: A global assessment of emissions and mitigation opportunities. Food and Agriculture Organization of the United Nations (FAO), Rome, http://www.fao.org/3/i3437e/i3437e.pdf

Jaenisch R, Eggan K, Humpherys D, Rideout W and Hochedlinger K, 2002. Nuclear cloning, stem cells and genomic reprogramming. Cloning Stem Cells, 4(4): 389-396, doi: 10.1089/ 153623002321025069

Hall B, Limaye A and Kulkarni AB, 2009. Overview: generation of gene knockout mice. Curr Protoc Cell Biol, Chapter 19: 19.12.1 19.12.17, doi: 10.1002/0471143030.cb1912s44

Hassan AU, Hassan G and Rasool Z, 2009. Role of stem cells in treatment of neurological disorder. Int J Health Sci, 3(2): 227-233.

He Z, Lu R, Zhang T, Jiang L, Zhou M et al., 2018. A novel recombinant human plasminogen activator: efficient expression and hereditary stability in transgenic goats and in vitro thrombolytic bioactivity in the milk of transgenic goats. PloS One, 13(8): e0201788, doi: $10.1371 /$ journal.pone.0201788

HerzogH, 2016. Farm Animal Suffering Leaves a Bad Taste In Your Mouth. Psychol. Today. Available on link at: https://works.bepress.com/haroldherzog/98/download/ (accessed October 03, 2018).

Ju H, Zhang J, Bai L, Mu Y, Du Y et al., 2015.The transgenic cloned pig population with integrated and controllable $\mathrm{GH}$ expression that has higher feed efficiency and meat production. Sci Rep, 5(1): 1-14, doi: 10.1038/srep10152

Kosnik PE, Dennis RG and Vandenburgh HH, 2003. Tissue engineering skeletal muscle. In: guilak F edn. Functional tissue engineering, vol 2003. Springer-Verlag, New York, pp 377-392, doi: 10.1007/0-387-21547-6_28 
Laible G, Smolenski G, Wheeler T and Brophy B, 2016. Increased gene dosage for $\beta$-and $\kappa$-casein in transgenic cattle improves milk composition through complex effects. Sci Rep, 6(1): 1-10, doi: 10.1038/srep37607

Langelaan ML, Boonen KJ, Polak RB, Baaijens FP, Post MJ et al., 2010. Meet the new meat: tissue engineered skeletal muscle. Trends Food Sci Tech, 21(2): 59-66, doi: 10.1016/ j.tifs.2009.11.001

Li B, Sun G, Sun H, Xu Q, Gao B et al., 2008. Efficient generation of transgenic chickens using the spermatogonial stem cells in vivo and ex vivo transfection. Sci China Ser C, 51(8): 734-42, doi: 10.1007/s11427-008-0100-2

Li Q, Hu W, Zhao J, Wang J, Dai Y et al., 2014. Supplementation transgenic cow's milk containing recombinant human lactoferrin enhances systematic and intestinal immune responses in piglets. Mol Biol Rep, 41(4): 211928, doi: 10.1007/s11033-014-3061-5

Mauro A, Turriani M, Ioannoni A, Russo V, Martelli A et al., 2010. Isolation, characterization, and in vitro differentiation of ovine amniotic stem cells. Vet Res Commun, 34(1): 25-8, doi: 10.1007/ s11259-010-9393-2

Miao X, 2013. Recent advances in the development of new transgenic animal technology. Cell Mol Life Sci, 70(5): 815-828, doi: 10.1007/s00018012-1081-7

Miar Y, Salehi A, Kolbehdari D and Aleyasin SA, 2014. Application of myostatin in sheep breeding programs: A review. Mol Biol Res Commun, 3(1): 33-43

Monin G and Sante-Lhoutellier V, 2014. Conversion of Muscle to meat: Color and Texture Deviations, Encyclopedia of Meat Sciences $\left(2^{\text {nd }}\right.$ edn.), pp 339-345, doi: 10.1016/B978-0-12384731-7.00097-0

Monzani PS, Adona PR, Ohashi OM, Meirelles FV and Wheeler MB, 2016.Transgenic bovine as bioreactors: challenges and perspectives. Bioengineered, 7(3): 123-131, doi: 10.1080/ 21655979.2016.1171429

Mozdziak PE, Borwornpinyo S, McCoy DW and Petitte JN, 2003. Development of transgenic chickens expressing bacterial betagalactosidase. Dev Dyn, 226(3): 439-45, doi: 10.1002/dvdy.10234

Niemann H, 2004. Transgenic pigs expressing plant genes. Proce Natl Acad Sci, 101(19): 7211-7212, doi: 10.1073/pnas.0402011101
Niemann H, Kuhla B and Flachowsky G, 2011. Perspectives for feed efficient animal production. J Anim Sci, 89: 4344-4363, doi: 10.2527/jas.2011-4235

Post M and van der Weele C, 2014. "Chapter 78 Principles of Tissue Engineering for Food," in Principles of Tissue Engineering, $4^{\text {th }}$ edn., R. Lanza, R. Langer, and J. Vacanti edn. (Boston, MA: Academic Press), pp 1647-1662, doi: 10.1016/B978-0-12-398358-9.00078-1

Richt JA, Kasinathan P, Hamir AN, Castilla J, Sathiyaseelan T et al., 2007. Production of cattle lacking prion protein. Nat Biotechnol, 25(1): 132-8, doi: 10.1038/nbt1271

Ricks CA, Mendu N and Phelps PV, 2003. The embryonated egg: A practical target for genetic based advances to improve poultry production. Poult Sci, 82(6): 931-938, doi: 10.1093/ps/ 82.6 .931

Rogers K, 2016. Cloning. Britannica Digital Learning, New York, pp vii

Sharma S, Thind SS and Kaur A, 2015. In vitro meat production system: why and how? J Food Sci Technol, 52(12): 7599-607, doi: 10.1007/ s13197-015-1972-3

Shepelev MV, Kalinichenko SV, Deykin AV and Korobko IV, 2018. Production of recombinant proteins in the milk of transgenic animals: current state and prospects. Acta Naturae, 10(3): 40-47, doi: 10.32607/20758251-2018-10-3-40-47

Singh B, Chauhan MS, Singla SK, Gautam SK, Verma V et al., 2009. Reproductive biotechniques in buffalo (Bubalus bubalis): status, prospects and challenges. Reprod Fertil Dev, 21(4): 499-510, doi: $10.1071 / \mathrm{RD} 08172$

Singh B, Gautam SK, Chauhan MS, Singla SK, Kumar S et al., 2011. Cellular Reprogramming- Advances and opportunities for Applications in Veterinary and Animal Sciences. In: Advances in Medicine and Biology (Berhardt LV, eds), Chapter-6, pp 195-214

Slade P, 2018. If you build it, will they eat it? Consumer preferences for plant-based and cultured meat burgers. Appetite, 125: 428-37, doi: 10.1016/ j.appet.2018.02.030

Stephens N, King E and Lyall C, 2018. Blood, meat, and upscaling tissue engineering: Promises, anticipated markets, and performativity in the biomedical and agri-food sectors. Biosocieties, 13(2): 368-388, doi: $10.1057 /$ s41292- 0170072-1 


\section{Role of stem cells in food producing animal}

Suchy F and Nakauchi H, 2017. Lessons from interspecies mammalian chimeras. Annu Rev Cell Dev Biol, 33: 203-217, doi: 10.1146/ annurev-cellbio-100616-060654

Tang KL, Caffrey NP, Nóbrega DB, Cork SC, Ronksley PE et al., 2017. Restricting the use of antibiotics in food-producing animals and its associations with antibiotic resistance in food-producing animals and human beings: A systematic review and meta-analysis. Lancet Planet Health, 1(8): e316-27, doi: 10.1016/S2542-5196(17) 30141-9

Umeyama K, Saito H, Kurome M, Matsunari H, Watanabe $\mathrm{M}$ et al., 2012. Characterization of the ICSI mediated gene transfer method in the production of transgenic pigs. Mol Reprod Dev, 79(3): 218-228, doi: 10.1002/mrd.22015

Van Eelen WF, van Kooten WJ and Westerhof W, 1999. WO/1999/031223: industrial production of meat from in vitro cell cultures. Patent Description, http://www.wipo.int/pctdb/en/wo.jsp? wo $=1999031223$

Vandamme TF, 2014. Use of rodents as models of human diseases. J Pharm Bioallied Sci, 6(1): 29, doi: 10.4103/0975-7406.124301

Viglio S, Iadarola P, D'Amato M and Stolk J, 2020. Methods of purification and application procedures of Alpha1 antitrypsin: A long-lasting history. Molecules, 25(17): 4014, doi: 10.3390/ molecules25174014

Vijayalakshmy K, Jacob N, Kumar D, Virmani M, Lalaji NS et al., 2018. Potential applications of stem cells in livestock production. Int $\mathrm{J}$ Curr Microbiol App Sci, 7(3): 67-77, doi: 10.20546/ ijcmas.2018.703.008
Weissman IL and Wagers AJ, 2004. Plasticity of adult stem cells. Cell, 116(5): 639-648, doi: 10.1016/ S0092-8674(04)00208-9

Williams J, 2012. Meat derived from stem cells: how, what and why. Research paper based on pathology lectures at Medlink, 1-10, http:// medlink-uk.net/wp-content/uploads/ pathprojectsstemcells2012/WilliamsJ.pdf.

Wolfson W, 2002. Raising the steaks. New Sci, 176: 60-63

Xu W, Jiang X and Huang L, 2019. RNA interference technology. Compr Biotechnol, 5: 560-575, doi: 10.1016/B978-0-444-64046-8.00282-2

Yadav PS, Singh RK and Singh B, 2012. Fetal stem cells in farm animals: applications in health and production. Agric Res, 1(1): 67-77, doi: 10.1007/ s40003-011-0001-7

Yu H, Chen J, Liu S, Zhang A, Xu X et al., 2013. Largescale production of functional human lysozyme in transgenic cloned goats. J Biotechnol, 168(4): 676-683, doi: 10.1016/j.jbiotec.2013.10.023

Zakrzewski W, Dobrzynski M, Szymonowicz M and Rybak Z, 2019. Stem cells: past, present, and future. Stem Cell Res Ther, 10(1): 68, doi: 10.1186/s13287-019-1165-5

Zhang PY, Fan Y, Tan T and Yu Y, 2020. Generation of artificial gamete and embryo from stem cells in reproductive Medicine. Front Bioeng Biotechnol, 8, doi: 10.3389/fbioe.2020.00781

Zhang YL, Zhang GM, Wan YJ, Jia RX, Li PZ et al., 2015. Identification of transgenic cloned dairy goats harboring human lactoferrin and methylation status of the imprinted gene IGF2R in their lungs. Genet Mol Res, 14(3): 1109911108, doi: 10.4238/2015.September.22.3 